Case report

\title{
Ertapenem Neurotoxicity in Patients with Kidney Damage: A Case Report
}

\author{
Alper Alp ${ }^{1}$, Yalkin Dalda ${ }^{2}$ \\ ${ }^{1}$ Mugla Sitki Koçman University, Faculty of Medicine, Department of Nephrology, Mugla, Turkey \\ ${ }^{2}$ University of Health Sciences, Tepecik Training and Research Hospital, Internal Medicine, Izmir, Turkey
}

\begin{abstract}
SUMMARY
Ertapenem, a member of the carbapenem group of antibiotics, is a broad-spectrum antibiotic that is effective against multidrug-resistant gram-positive and gram-negative infections. In patients with acute or chronic kidney damage, one of the most serious side effects of ertapenem is neurotoxicity. Various clinical conditions such as seizures, hallucinations, delirium, confusion, and nystagmus may occur. Previous history of cerebral pathologies is a known risk factor for ertapenem-associated neurotoxicity. Immediate discontinuation of treatment is required. Although the symptoms usually resolve rapidly, cases with longer duration of symptoms have also been reported. Close monitoring of neurological status in such patients is essential.
\end{abstract}

Key words: ertapenem, seizures, kidney injury

Corresponding author:

Alper Alp

e-mail: alperalp@mu.edu.tr 


\section{INTRODUCTION}

Ertapenem, a member of the carbapenem group of antibiotics, is a broad-spectrum antibiotic that is effective against multidrug-resistant grampositive and gram-negative infections and is preferred for patients requiring inpatient treatment. It is the primary choice for extended spectrum betalactamase (ESBL)-positive urinary tract infections. This antibiotic can cause central nervous system toxicity and lower the seizure threshold, and patients should be monitored carefully for neurological symptoms. In this paper, we present two patients with acute and chronic kidney injury who developed central nervous system side effects following intravenous ertapenem use. Informed consent from both patients was obtained.

\section{CASE REPORT}

Patient 1 was a 66-year-old man who suffered from epilepsy with a history of cranial surgery and secondary left hemiplegia following head trauma 20 years earlier. He reported having his last epileptic seizure 20 years before under $200 \mathrm{mg} /$ day carbamazepine therapy. His previous history of kidney disease was unspecific, and a follow-up in the nephrology department was initiated due to incidental findings of elevated blood urea nitrogen and serum creatinine levels. Baseline laboratory findings at the time of presentation were as follows: blood glucose: $6.83 \mathrm{mmol} / \mathrm{L}$, albumin: $24 \mathrm{~g} / \mathrm{L}$ urea: 34.29 $\mathrm{mmol} / \mathrm{L}$, creatinine: $274.5 \mu \mathrm{mol} / \mathrm{L}$, sodium: $135 \mathrm{mmol}$ /L, potassium: $4.79 \mathrm{mmol} / \mathrm{L}$, thyroid stimulating hormone: $0.877 \mu \mathrm{IU} / \mathrm{ml}$, corrected calcium: $2.35 \mathrm{mmol} / \mathrm{L}$, phosphorus: $1.2 \mathrm{mmol} / \mathrm{L}, \mathrm{C}$-reactive protein: 232.4 $\mathrm{mg} / \mathrm{L}$, procalcitonin: $0.86 \mu \mathrm{g} / \mathrm{L}$. Urinalysis revealed: protein: +1 , leukocytes: +1 , erythrocytes: +3 , white blood cell count: 22800 (neutrophil 20900), hemoglobin: $84 \mathrm{~g} / \mathrm{L}$, hematocrit: 0.27 , and platelet count: 455,000 . Urinary ultrasonography revealed grade $2-$ 3 bilateral pelvicaliectasis and a diverticulitis $16 \mathrm{~mm}$ in diameter in the right lateral bladder wall. A nephrostomy catheter was placed by a consultant from the urology department. High fever, pyuria, and elevated acute phase reactants were detected during a follow-up in the nephrology department, and empirical ertapenem therapy was initiated at a dose of $500 \mathrm{mg}$ once a day. Sensitive Escherichia coli was isolated in the patient's urinary culture and his current antibiotherapy was continued. On the eighth day of antibiotic therapy, the patient developed a secondarily generalized epileptic seizure, and a neurologist's examination was ordered. He showed no response to diazepam, after which the neurologist initiated phenytoin infusion and adjusted the carbamazepine dose to $200 \mathrm{mg}$ three times a day. At the time of the occurrence of seizure, his treatment con-
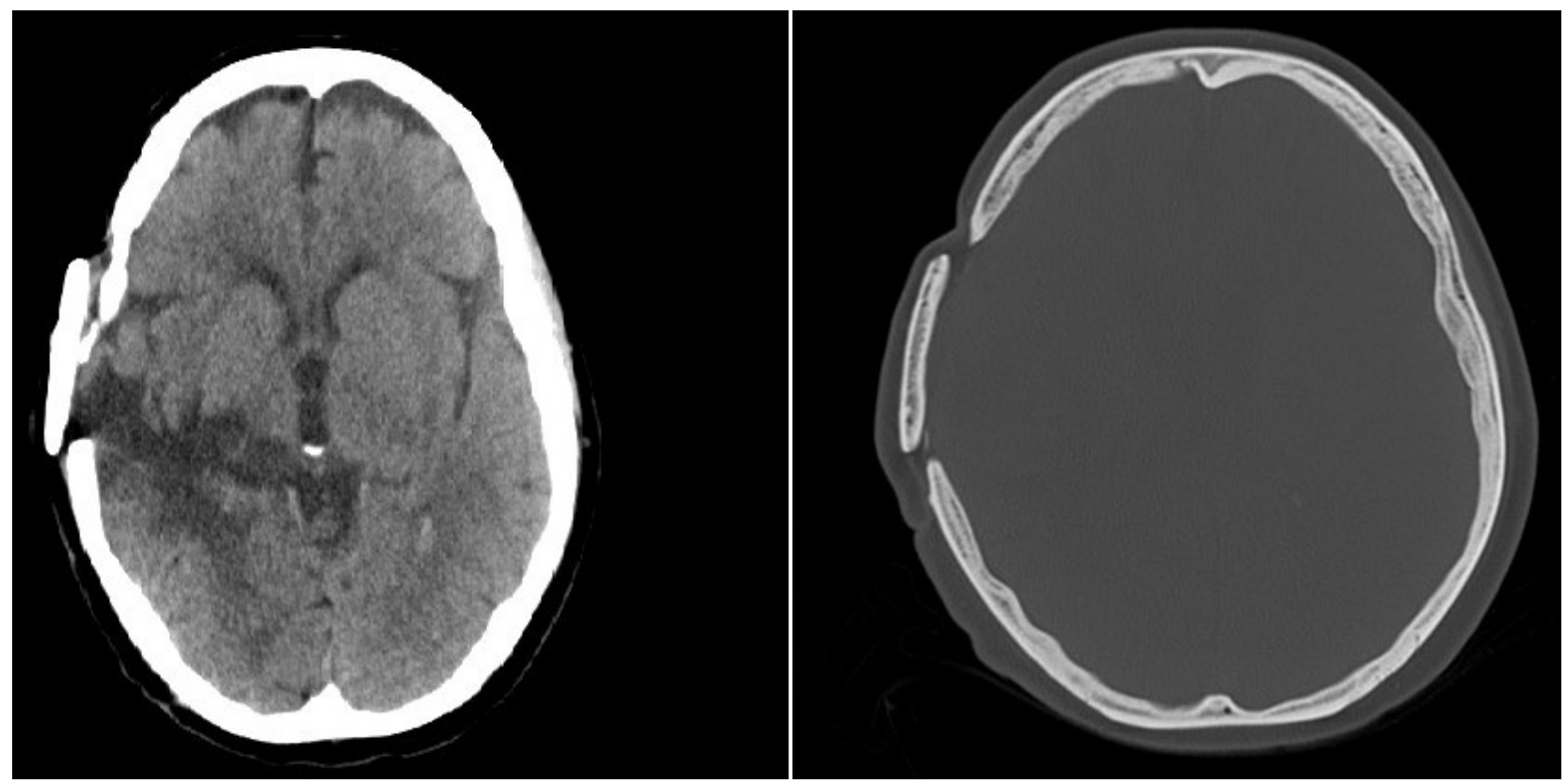

Figure 1. Cranial CT: Right frontotemporal craniotomy defect and adjacent encephalomalacic changes. Differentiation of the cortical sulci and gyri; mild dilation and cerebral atrophy in the ventricular system 
sisted of pantoprazole, calcium carbonate, sodium hydrogen, calcitriol, baclofen, amlodipine, $200 \mathrm{mg}$ carbamazepine once a day, $500 \mathrm{mg}$ ertapenem once a day, and enoxaparin. No acute central nervous system pathologies were detected on cranial imaging (Figure 1). He was transferred to the intensive care unit. Because we speculated that ertapenem provoked epileptic seizures, his antibiotic was changed to meropenem, which he received for three days. After discontinuing ertapenem therapy, the patient had no more seizures and was discharged after his nephrologic treatment was completed. Laboratory results on discharge were: urea: $14.31 \mathrm{mmol} / \mathrm{L}$, creatinine: $185.64 \mu \mathrm{mol} / \mathrm{L}$, sodium: $139 \mathrm{mmol} / \mathrm{L}$, potassium: $3.83 \mathrm{mmol} / \mathrm{L}$, corrected calcium: $2.30 \mathrm{mmol} / \mathrm{L}$, and phosphorus: $1.03 \mathrm{mmol} / \mathrm{L}$.

Patient 2 was a 65-year-old woman with a history of chronic kidney disease (baseline creatinine: $274.5 \mu \mathrm{mol} / \mathrm{L}$ ) secondary to hypertension. She presented to the emergency department with shortness of breath. Admission laboratory tests were: blood glucose: $6.99 \mathrm{mmol} / \mathrm{L}$, urea: $63.93 \mathrm{mmol} / \mathrm{L}$, creatinine: 655,75 $\mu \mathrm{mol} / \mathrm{L}$, sodium: $138 \mathrm{mmol} / \mathrm{L}$, potassium: 5.1 mmol/L, white blood cell count: 11400 (neutrophil 10400), hemoglobin: $85 \mathrm{~g} / \mathrm{L}$, hematocrit: 0.265 , and platelet count: 248000 . Urinalysis showed leukocytes: +3 , erythrocytes: +2 and arterial blood gas $\mathrm{pH}: 6.91$, $\mathrm{HCO}_{3}$ : 5.4, lactate: $1.7, \mathrm{pCO}_{2}:$ 18.8. Emergency hemodialysis was scheduled and the patient was monitored in the ward. Empirical ceftriaxone treatment was initiated due to dysuria and lower abdominal pain. During inpatient follow-up, C-reactive protein was $185 \mathrm{mg} / \mathrm{L}$ and procalcitonin with the value of $7.26 \mu \mathrm{g} / \mathrm{L}$ was noticed, resulting in antimicrobial treatment change to ertapenem $500 \mathrm{mg}$ once a day on the second day of treatment. On the fifth day of antibiotic therapy, during the hemodialysis session, the patient experienced an acute alteration in mental status, and a physical examination revealed time/place disorientation accompanied by myoclonic twitches. Cranial imaging was performed and the neurologist was consulted. Computed tomography (CT) revealed no significant pathologies other than diffuse reduction in density secondary to chronic ischemic changes in the periventricular and subcortical white matter and chronic lacunar infarcts in the bilateral external capsules. Cranial MRI demonstrated chronic lacunar infarct at the bilateral basal ganglia and multiple nonspecific ischemic-gliotic foci scattered in the white matter of both cerebral hemispheres that were iso- to hypointense compared to the normal gray matter in T1-weighted series and hyperintense in T2-weighted series. Diffusion MRI was normal. No lateralized motor deficits were detected and no acute central nervous system pathologies were apparent on cranial imaging. The patient did not develop a fever and her acute phase reactant levels decreased during the follow-up. She was reevaluated by an infectologist and her treatment with ertapenem 500 $\mathrm{mg}$ once a day was discontinued after seven days of antibiotherapy. Her neurological symptoms and disorientation completely resolved after cessation of ertapenem treatment and she was discharged two days later with completely normal neurological finding.

\section{DISCUSSION}

Some adverse reactions have been identified for ertapenem. Apart from anaphylactoid reactions, gastrointestinal effects (diarrhea is the most common), fungal/bacterial superinfections, elevated liver function tests, headache, and local effects such as phlebitis may be seen.

One of the most important side effects of carbapenem group antibiotics is neurotoxicity. Imipenem in particular is known to cause seizures in $0.4-$ $7.5 \%$ of patients (1). Carbapenems are believed to lower the seizure threshold and possibly cause a tendency toward psychotic symptoms such as hallucinations by antagonizing inhibitory neurotransmitters ( $\gamma$-aminobutyric acid-GABA) in the central nervous system. In the pathophysiology of ertapenem-associated neurotoxicity, affinity of the C2 side chain to $\gamma$-aminobutyric acid neurotransmitter and antagonism in the receptor region (GABA type A), increased permeability of the blood-brain barrier in those with renal dysfunction but impaired active transport from the CSF to the blood, basicity of the amine group in the side chain of the second carbon atom, distance from the carboxyl to the amino group and structural distortion around the amino group have been cited as important factors (2). A growing number of studies and case presentations in the recent literature have emphasized the central nervous system side effects of ertapenem. Eighty percent of ertapenem is eliminated by the kidneys. It is $94 \%$ protein-bound in the circulation. Its half-life is normally $4-5$ hours but can be over 10 hours in the presence of kidney damage. It has good central nervous system penetration. Various clinical conditions 
such as seizures, hallucinations, delirium, confusion, and nystagmus may occur (3). Although the reported incidence of these side effects is less than $1 \%$, the use of ertapenem has increased in recent years, particularly due to its ease of use, as its long half-life allows it to be administered in a single daily dose. In their study including 1,706 patients treated with ertapenem, Lee et al. determined the incidence of seizure to be $1.9 \%$ (4). It was shown that ertapenem can lead to acute mania by lowering the levels of valproic acid (5). Previous history of cerebral pathologies is a known risk factor for ertapenem-associated neurotoxicity (6). Our first patient had a history of cranial surgery, but our second patient exhibited neurotoxicity despite a lack of any relevant history. Renal function was likely the predisposing factor in our second patient. Similar to our second case, Hanna et al. reported a patient under routine hemodialysis who had no history of neurological disorders but exhibited altered mental status and vocal tremor despite the use of $500 \mathrm{mg} /$ day (7). In patients with glomerular filtration rate under $30 \mathrm{ml} / \mathrm{min}$, the recommended dose of ertapenem is $500 \mathrm{mg} /$ day. Both of the patients in this case showed developed neurotoxic side effects despite using ertapenem at the renal dose of $500 \mathrm{mg} /$ day. Lee et al. measured blood ertapenem levels and demonstrated that even this dose can cause toxicity in routine hemodialysis patients, despite the fact that up to $70 \%$ is eliminated by hemodialysis (4). Again, in the study of El Nekidy et al., it was emphasized that the neurotoxic effects could continue in CKD-5D patients at a dose of 500 $\mathrm{mg} /$ day and it was stated that alternative dosage or administration strategies should be developed (8). Central nervous system toxicity with ertapenem use generally occurs in the geriatric population. Similarly, both of our patients were 65 years of age or older.

Carbapenem antibiotics, especially ertapenem, should be used with caution and close neurological monitoring in elderly patients (who have relatively low creatinine levels secondary to decreased muscle mass) and in patients with low glomerular filtration rate, existing central nervous system pathologies, and hypoalbuminemia. Immediate discontinuation of treatment is the first intervention. Although the symptoms usually resolve rapidly, prolonged cases have also been reported. In future medical treatment, it must be kept in mind that similar effects can be observed with ertapenem or other carbapenems.

\section{Conflict of interest statement}

The authors have declared no conflicts of interest.

\section{Ethics}

An informed consent from patients was obtained. 


\section{References}

1. Deshayes S, Coquerel A, Verdon R. Neurological Adverse Effects Attributable to $\beta$-Lactam Antibiotics: A Literature Review. Drug Saf. 2017;40(12):1171-98.

https://doi.org/10.1007/s40264-017-0578-2

2. Hsaiky LM, Salinitri FD, Wong J, et al. Pharmacokinetics and investigation of optimal dose ertapenem in intermittent hemodialysis patients. Nephrol Dial Transplant.

2019;34(10):1766-72.

https://doi.org/10.1093/ndt/gfy166

3. Miller AD, Ball AM, Bookstaver PB, et al. Epileptogenic potential of carbapenem agents: mechanism of action, seizure rates, and clinical considerations. Pharmacotherapy. 2011; 31(4): 408-23.

https://doi.org/10.1592/phco.31.4.408

4. Lee YC, Huang YJ, Hung MC, et al. Risk factors associated with the development of seizures among adult patients treated with ertapenem: A matched case-control study. PLoS One. 2017;12(7):e0182046. https://doi.org/10.1371/journal.pone.0182046
5. Molnar GP, Stephens KJ, George LV, Stewart JT. A critical interaction between ertapenem and valproic acid. J Clin Psychopharmacol. 2015; 35(3): 348-50.

https://doi.org/10.1097/JCP.0000000000000325

6. Fica AE, Abusada NJ. Seizures associated with ertapenem use in patients with CNS disorders and renal insufficiency. Scand $\mathrm{J}$ Infect Dis. 2008;40(11-12):983-5.

https://doi.org/10.1080/00365540802375570

7. Hanna RM, Sun SF, Gaynor P. A Case of Ertapenem Neurotoxicity Resulting in Vocal Tremor and Altered Mentation in a Dialysis Dependent Liver Transplant Patient. Antibiotics (Basel). 2018;8(1):1. https://doi.org/10.3390/antibiotics8010001

8. El Nekidy WS, Elrefaei H, St John TJL, et al. Ertapenem Neurotoxicity in Hemodialysis Patients-Safe and Effective Dosing Is Still Needed: A Retrospective Study and Literature Review. Ann Pharmacother. 2021;55(1):52-8. https://doi.org/10.1177/1060028020938059 


\title{
Neurotoksičnost ertapenema kod bolesnika sa oštećenjem bubrega: prikaz slučaja
}

\author{
Alper Alp1, Yalkin Dalda² \\ -1Univerzitet Sitki Kocman u Mugli, Medicinski fakultet, Departman za nefrologiju, Mugla, Turska \\ 2Univerzitet zdravstvenih nauka, Bolnica za obuku i istraživanje Tepecik, Interna medicina, Izmir, Turska
}

\section{S A ŽETAK}

Ertapenem, antibiotik iz grupe karbapenema, je lek širokog spektra delovanja, koji je efikasan u lečenju gram pozitivnih i gram negativnih infekcija otpornih na više lekova. Kod bolesnika sa akutnim ili hroničnim oštećenjem bubrega, jedna od najozbiljnijih nuspojava ertapenema je neurotoksičnost. Mogu se javiti različita klinička stanja, kao što su napadi, halucinacije, delirijum, konfuzija i nistagmus. Prethodna istorija cerebralnih patologija predstavlja poznati faktor rizika od pojave neurotoksičnosti izazvane ertapenemom. U tom slučaju, potreban je hitan prekid lečenja. Iako se simptomi obično brzo povlače, zabeleženi su i slučajevi sa dužim trajanjem simptoma. Pažljivo praćenje neurološkog statusa kod takvih bolesnika je od suštinskog značaja.

Ključne reči: ertapenem, napadi, oštećenje bubrega 